\title{
Constraints in Effective Management of HIV/AIDS with Antiretroviral (ARV) Therapy in Nigeria
}

\author{
Dr. G.O. Ayenigbara \\ Science and Technical Education Department, Adekunle Ajasin University, Akungba-Akoko, \\ Ondo State, Nigeria
}

\begin{abstract}
Human Immunodeficiency Virus (HIV) which causes Acquired Immunodeficiency Syndrome (AIDS) originated in Africa. HIVIAIDS has since assumed a pandemic health problem whose ravaging effects had claimed millions of lives all over the world. The spread of the disease in Nigeria is continuing unabated, particularly among the youths, sex workers, military and paramilitary personnel, long distance drivers, migrant workers, students, and the Police. There is no cure for now except the suppression of the viral load through anti-retroviral drugs (ARV). ARV drugs are scarce in Nigeria. The drugs are expensive while the administration requires strict medical supervision. Its use has side effects. These factors causes non-compliance and non-adherence to the drug regimen. Successful use of ARV drugs depends largely on compliance and adherence to the drug regimen. Non-adherence could lead to the emergence of drugs resistant strains, which would complicate health crisis. Suggestions on what government can do to ensure compliance and adherence were made.
\end{abstract}

Keywords-Human Immunodeficiency Virus (HIV), Acquired Immunodeficiency Syndrome (AIDS), Anti-retroviral drugs (ARV), Regimen Adherence

\section{INTRODUCTION}

Human Immunodeficiency Virus (HIV) infection is one of the most serious and challenging health problems facing the United States and the World today. Worldwide, it is estimated that more than 60 million people have been infected since the epidemic began i.e. nearly $1 \%$ of the world's population, and that more than 20 millions have died (Insel and Roth, 2006). About 10 people are infected every minute, 5 million per year and half of those new infections are in people age 15-24 years. According to Lamptey, (2002), HIV/AIDS is the deadliest plague in history. About 40 million people were infected by 2001; when those people die, HIV will surpass the number of people killed by the bubonic plague in the $14^{\text {th }}$ century.

The majority of cases of HIV infections, 95\% have occurred in developing countries, including Nigeria, where heterosexual contact is the primry means of transmission, responsible for $85 \%$ of all adult infections (Insael and Roth, 2006). Though HIV/AIDS is a relatively new disease in humans, experts (Moore, 2004, Insel and Roth 2006; Brannon and Feist, 2007), believed that the virus, first recognized in 1981 and identified in 1983, originated in Africa in a virus that affects monkeys and chimpanzees. However, despite the best efforts of health professionals around the world, HIV infections continue to spread, and a cure is yet to be found (Sahloff 2005).

The health problems posed by HIV/AIDS ae almost becoming in surmountable. HIV/AIDS has no age, social, racial, geographical, educational or occupational barrier, and its disastrous effects touch every segment of human endeavour. All efforts so far made at combating this dreadful pandemic had only succeeded in reducing HIV/AIDS from being a death sentence to the group of manageable chronic diseases. This development was due to the discovery of antiretroviral (ARV) drugs that prolongs the life of HIV/AIDS victims. This increased survival time is a result of more effective drug therapies, early detection and lifestyle changes (Egger et-al, 2002). In addition, giving up unhealthy habits such as smoking, drinking alcohol, and taking illicit drugs, becoming more vigilant about their health; and exercising more control over their treatment can help infected persons live longer and healthier lives (Chou, Holzemer, Portillo, and Slaughter, 2004). An optimistic attitude also contributed to longevity (Moskowitz, 2003).

Moreover, ARV drugs, when property administered would suppress and reduce the viral load in the body and improve clinical outcomes. Though ARV is not a cure for HIV/AIDS, it is the only means, for now, to stop those already affected from becoming ill for many years. Also, ARV would enable HIV/AIDS patients to live a near normal life, improve quality of life and allows him or her to be productive in life. 
Even though ARV drugs have the potential for transforming HIV/AIDS into the group of manageable chronic diseases, the drugs have some problems to contend with. ARV drugs are very expensive comparatively in Nigeria, they are also scarce. Available ARV drugs are, more often than not, priced beyond the reach of HIV/AIDS patients. When the high prices and the scarcity are viewed in relation to the impoverishness, helplessness and hopelessness ravaging the developing nations, including Nigeria, the option of ARV therapy might be a mirage, as adherence to the drug regimen becomes impossible.

Of equal importance is the near absence of qualified medical personnel to supervise the administration of ARV drugs due to incessant brain drain from African Countries, including Nigeria to well-to-do nations. Thorough supervision is essential in ARV drugs administration to ensure compliance, because non-compliance with ARV regimen would definitely lead to the emergence of drugs resistant strains, which invariably would complicate the health crisis. It is in view of this and other problems that this paper examined the constraints in effective control of HIV/AIDS with ARV drugs in Nigeria with the intention of providing possible solutions.

\section{CURRENT HIV/AIDS STATUS IN NIGERIA}

HIV/AIDS, a pandemic disease is still ravaging the third World countries, including Nigeria. Since the first prevalence survey in 1992 came out with a result of 1.8\% (Osotimehin, 2004) the National average had steadily in 12 years grown up to 5.8\%. National Action Committee on AIDIS (NACA) Director General (Osotimehin 2004), observed that individual states across the regions had the following prevalence rates; Anambra 6.5\%; Abia 3.5\%; Ondo 6.7\%; Ekiti 3.2\% Kaduna 5.6\%; Akwa Ibom 10.7\%; Jigawa 1.8\%; (the least Nationwide); Gombe 8.2\%; Yobe 3.5\%; Edo 5.7\%; and Benue 30.5\% (the highest). According to him, $95 \%$ of new infections are in people aged 15-25 and the primary means is heterosexual sex. Other means through which the virus is transmitted include tainted blood supply, pregnancy, delivery and breast feeding, and among homosexual partners (Hall, 1994; WHO, 2001). The under 40 years age group constitutes the most-at-risk population. Incidentally, $65 \%$ of Nigerians fit in with this group (Osotimehin, 2004).

\section{POPULATION AT HIGH RISK OF HIV/AIDS INFECTION}

Prevalence of HIV/AIDS is high among adolescents because of the social, physical and emotional characteristics that are peculiar to them. Adolescent boys and girls are adventurous, they take risks, they use drugs, and they involve themselves in adult activities including sexual activities (Morgan and King, 1979). Also students of tertiary institutions are at risk. Tertiary institutions including Universities are breeding ground and are conduits for HIV/AIDS transmission (Gestso, 2004).

Also at high risk are the police, paramilitary, (immigration, customs), and military personnel. Not excluded is the prison populati9on in which a likely homo-sexual practice goes on with a price of nearly $25 \%$ seroprevalence among men. According to Osotimehin (2004), the military are responsible for some of the outbreaks we have had, especially those of them who have gone on services outside Nigeria. Other group of people at high risk are the commercial sex workers and long distance drivers. One out of every three commercial sex worker carries the virus, and up to $66 \%$ in some locations, while long-distance drivers are stuck with $35 \%$ prevalence rate (Osotimehin, 2004).

\section{ANTI-RETROVIRAL (ARV) THERAPY}

Though, the Anti-retroviral drugs (ARV) are not a cure for HIV/AIDS, they are the only means to stop those already affected from becoming ill for many years. The use of ARVS in developed countries have dramatically reduced death rate from HIV/AIDS, and has improved the quality of lives of people living with it. ARV have also transformed HIV/AIDS, from fatal condition to a manageable chronic illness. In the developed countries, people living with HIV/AIDS lead productive lives largely due to ARV drugs (Gestso 2004).

Current Antiretroviral drugs (ARVS) in use include Nevirapine, Stavudine, and Lamivudine. Beyond the use of ARV drugs, it is pertinent to emphasise the recognition of good food, as well as stress free and depression free sosciety and economically empowered citizenry. Unfortunately these are lacking in our chronically impoverished society. There is no denying the direct and or indirect link of poverty begets diseases and diseases beget poverty to diseases. Poverty all tied in a cyclical ring that continue to destroy third world countries.

Even though ARVS are effective for the management of AIDS, there is the problem of emerging resistant strains of HIV to contend with. The more potent and effective new combinations of anti-retroviral drugs known as Highly Active Anti-retroviral Therapy (HAART) have proven efficacious in reducing viral load and improving clinical outcomes. However, there is the need for strict adherence. The large number of indications involved, the complicated dosing requirement and the sub-optimal tolerability of the remarkably efficacious multi-drug regimes of HAART make adherence difficult. 
Adherence is particularly important when HAART is used. Initially, it was thought that HAART would completely eradicate the virus from host but due to the presence of resting $\mathrm{T}$ cells in the body which harbour proviral DNA, and the low viral replication that persist in small reservoir, complete eradication could not be achieved with HAART. However, almost perfect adherence may lead to lasting viral suppression.

\section{PROBLEMS OF ARVS THERAPY}

Anti-retroviral (ARVS), for now are indispensable in the management of HIV/AIDS until a cure is found. As effective as ARVS, there are some problems bedeviling its use in the third world countries, including Nigeria. Currently in Nigeria, there are moans of helplessness among HIV/AIDS patients and their families over the non-availability of ARVS and the dearth of well trained medical personnel to effectively manage the administration of ARVS to patients. The consequence of this is the sudden fall in optimism over effective containment of the resilient disease. Another problem is that ARVS administration has rules that must be complied with. Various kinds of ARVS such as first line, second line and salvage therapy exist. The resistance to one group does not necessarily means resistance to others. ARVS administration must follow a consistency, a violation of which could predictably result in development of resistance to the virus. Trained medical personnel must know when drug causes side effects, which alternative therapy to switch to, and when to start a patient on ARVS. Trained personnel to manage ARVS are not available in Nigeria. Knowledge of ARVS and their administration are largely non existent among the available medical personnel, leading to confusion as to which of the very many brands of ARVS available in the world market to use of stop using (Ohaeri 2004).

Moreover, there are disparities in the drug charges by various dispensing units in Nigeria. Ohaeri (2004) noted that Federal Ministry of Health doles out intermittently to a handful of 10,000 patients a month at N12,000.00 per patient. And charges for ARV by State Ministry of Health and some multinational pharmaceutical companies run into N56,000 a month per patient. Intermittent supply apart, these charges are grossly exorbitant causing the drugs to be out of reach of majority of HIV/AIDS victims.

Non-adherence to ARV regimen is another problem. Adherence is the extent to which a patient's medication-taking behaviour corresponds with agreed recommendations from a health care provider irrespective of diet or life style changes. Good adherence is a decisive factor in treatment success. Unlike other chronic diseases, the rapid replication and mutation rate of HIV means that very high levels of adherence are required to achieve durable suppression of viral load. Suboptimal adherence may rapidly lead to resistant strains of this virus and this facilitates easy transmission of the virus to other people.

Non-adherence to Highly Active Anti-retroviral Therapy (HAART) can have important Public Health Implications. Drug resistant strains of HIV may be transmitted to other persons during high-risk activity, which can then limit therapeutic options. According to Ohaeri (2004), some studies have reported that as many as $80 \%$ of isolates from newly infected people are resistant to at least one of the currently approved antiretroviral medications, and that $26 \%$ of isolates are resistant to several classes of medication. This suggests that the development of drug resistant strains is increasing.

\section{CAUSES OF NON - ADHERENCE TO ARV REGIMEN}

Non-adherence to ARV like many other drugs, may be caused by a number of factors. For instance, as complexity of regimen for many chronic diseases such as Tuberculosis, Leprosy and HIV/AIDS (i.e the number of pills per dose and number of doses per day) increases, adherence decreases (Lucas and Gilles 1973, Ogba 2004). Regimens that involve close monitoring and severe life style alteration together with side effects may lead not only to frustration and treatment fatigue, but also ultimately to non-compliance. Regimen requiring fewer alterations in lifestyle pattern is likely to have a positive influence on adherence to medication.

Side effects have also contributed in no small measure to the decreased adherence in patients who experience adverse reactions. HAART regimen usually have temporary side effects including transient reactions such as diarrhea and nausea as well as longer lasting effects such as lipodystrophy and neuropathy Ogba, 2004). Lipodystrophy, according to the author affects between $30 \%$ and $60 \%$ of persons on HAART.

Non-adherence may also be caused by non-availability of ARV drugs. As in Nigeria where according to Ohaeri (2004) the Federal Government doles out intermittently disrupted ARVS supplies, when the available drugs are exhausted, HIV/AIDS patients may not be able to continue the regimen and this may result in nonadherence. 
Constraints in effective management of hiv/aids with antiretroviral (arv) therapy in nigeria

Also worthy of note is the exorbitant cost of ARVS. As a result of the high cost of the drugs HIV/AIDS patients, majority of who come from poor background, may not be able to continue with their treatment. The resultant effect would be non-adherence and the development of drugs resistant strains.

\section{SUGGESTIONS TO IMPROVE ADHERENCE TO ARVS REGIMEN}

To improve adherence to ARV including HAART regimen, health care providers should work to establish a collaborative treatment relationship with HIV/AIDS victims. This can be fostered by involving the patients in selecting regimens with dosing schedules, pill burdens and side effects, that they believe are tolerable and will fit into their daily lives.

Appropriate attention to mental illness, as well as to intake of alcohol and drugs could greatly enhance adherence to medical treatment of HIV/AIDS. Of equal importance is the attitude of the patients generally to life on the one hand and attitude of the public including the government to the victims. The government at all levels should make ARVS readily available at designated centres, at affordable prices and at regular intervals. Accessibility of ARVS to HIV/AIDS patients will greatly enhance adherence.

More well trained and competent medical personnel should be recruited and be available to administer ARVS, while the public at large should show love, affection and interest towards the patients. If HIV/AIDS patients are encouraged to comply with ARVS regimen, their lives would be prolonged, and who knows, in the process of adherence permanent solution may be found.

Furthermore, the government at all levels should demonstrate sincere commitment and political-will in making ARV drugs available to HIV/AIDS patients free of charge, and in employing more competent and certified medical personnel to supervise the administration of the drugs. HIV/AIDS patients should be encouraged to comply with ARV regimen until a cure could be found.

\section{REFERENCES}

[1]. Acheson, E.D (1986). A Change for the Public Health, Lancet, 1, 66-76.

[2]. Alade, T. (2001). Public Health Nutrition ( $2^{\text {nd }}$ ed.) Tosco Ventures Press, Ilorin.

[3]. Brannon, L; and Feist, J. (2007). Health Psychology: An Introduction to Behaviour and Health, $6^{\text {th }}$ ed. Thomson Wadsworth, New York.

[4]. Brettle, R.P. et0al (1987).Human Immunodeficiency Virus and Drug Misuse: The Edinburgh Experience, Br. Med. 295 , 421-424.

[5]. Chou, F; Holzemer, W.L; Portillo, C.J; and Slaughter, R. (2004).

[6]. Self-Care Strategies and Sources of Information for HIV/ADIS Symptom Management.Nursing Research, 53, 332-339.

[7]. $\quad$ Egger, M; Mag. M; Chene, G; Phillips, A.N; Lendenberger, B. Dabis, F; (2002). Prognosis of HIV-I infected Patients starting highly active antiretroviral therapy: A Collaborative Analysis of Prospective Studies. Lancet, 360, 119-129.

[8]. Gesto, A.M. (2004).Nigerian Schools and HIV/aids: The Team Approach Solution.Nigerian School Health Journal 16, 1 and 2.

[9]. Hall, P. (1994). Health Skills for Wellness, New Jersey, |Eagle Wood Cliff.

[10]. Insel, P.M; and Roth, W.T. (20060). Core Concepts in Health. $10^{\text {th }}$ ed. McGraw Hill, New York.

[11]. Lamptey, P.R. (2002). Reducing Heterosexual Transmission of HIV in poor Countries. British Medical Journal, $324,207-211$.

[12]. Lucas, A.O. and Gilles, H.M. (2003).A Short Textbook of Preventive Medicine for the Tropics. Hodder and Stoughton, London.

[13]. Maisto, S.A; Galizio, M; and Connors, G.I. (1999). Drug Use and Abuse, $3{ }^{\text {rd }}$ ed. Harcourt Brace and Company.

[14]. Moore, J; (2004). The Puzzling Origins of AIDS. American Scientist, 92, 540-547.

[15]. Morgan, C.T; and King R.A. (1979). Introduction to Psychology, New York, Mc Graw-Hill Book Company.

[16]. Moskowitz, J.T. (2003).Positive affect predicts lower risk of AIDS Mortality.Psychosomatic Medicine, 65, 620-626.

[17]. Ogba, E. (2004). Non Adherence to HIV/AIDS Therapy is Dangerous, Pharmanews, Nigeria's Foremost Health Journal, 26.7.

[18]. Ohaeri, R (2004).Osotimehin Advocates better Communication to Combat AIDS.Pharmanews, Nigeria's Foremost Health Journal, 26.7.

[19]. Osotimehin, B. (2004).Advocates of Better Communication to Combat AIDS. Pharmanews, Nigeria's Foremost Health Journal, 26.7

[20]. Sahloff, E.G. (2005).Current Issues in the Development of a Vaccine to Prevent Human Immunodeficiency Virus. Pharmacotherapy, 25, 741-747.

[21]. World Health Organisation (WHO),(2001).Developing Countries and HIV/AIDS.WHO Chronicles, 102 (5) 16-20.

[22]. Young, L.S. (1987).Treatable Aspects of INFECTION DUE TO Human Immunodeficiency Virus.Lancet, $1503-1506$. 